\title{
Solid fraction of separated digestate as soil improver: implications for soil fertility and carbon sequestration
}

\author{
Caleb Elijah Egene ${ }^{1}$ (D) I Ivona Sigurnjak ${ }^{1} \cdot$ Inge C. Regelink ${ }^{2} \cdot$ Oscar F. Schoumans $^{2} \cdot$ Fabrizio Adani $^{3} \cdot$ Evi Michels $^{1}$. \\ Steven Sleutel ${ }^{4} \cdot$ Filip M. G. Tack ${ }^{1}$ • Erik Meers $^{1}$
}

Received: 14 April 2020 / Accepted: 28 September 2020 / Published online: 17 October 2020

(C) The Author(s) 2020

\begin{abstract}
Purpose This study investigated the $\mathrm{C}$ and $\mathrm{N}$ mineralisation potential of solid fractions (SFs) from co-digestated pig manure after P-stripping (P-POOR SF) in comparison with P-rich SFs, as a means to estimate their organic matter stability in soil. Compost (COMP) and biochar (BCHR) (made from P-POOR SF) were also included in the study as reference biosolids.

Methods The SFs were incubated in a sandy-loam soil under moist conditions to determine production of $\mathrm{CO}_{2}$ and mineral $\mathrm{N}$. At specified intervals, $\mathrm{CO}_{2}$ evolution in the mixtures was measured via the alkali trap method and titration over a period of 81 days, while mineral $\mathrm{N}$ was measured using a flow analyser after $\mathrm{KCl}$ extraction over a period of 112 days.

Results The various SFs showed similar patterns of C mineralisation (15-26\% of added total C in 81 days) that were clearly higher than for COMP and BCHR (6\% and 7\%, respectively). Temporary $\mathrm{N}$ immobilisation was observed in biosolids with a high $\mathrm{C} / \mathrm{N}$ ratio. The effective organic matter (EOM) of the SFs was calculated based on the $\mathrm{C}$ mineralisation data and varied between 130 and $369 \mathrm{~kg} \mathrm{Mg}^{-1}$.

Conclusions The SF with a reduced $\mathrm{P}$ content had a high EOM/P ratio which is beneficial in areas where $\mathrm{P}$ status of the soil is already high. Moreover, the $\mathrm{N}$ mineralisation patterns confirm that a high $\mathrm{C} / \mathrm{N}$ ratio may also reduce risks for $\mathrm{N}$ leaching due to temporary $\mathrm{N}$ immobilisation.
\end{abstract}

Keywords Soil organic matter $\cdot$ Solid fraction $\cdot$ Digestate $\cdot \mathrm{C} / \mathrm{N}$ ratio $\cdot$ Mineralisation

\section{Introduction}

Over the last decade, European Union (EU) policy oriented towards developing a circular and resource-efficient economy

Responsible editor: Caixian Tang

Caleb Elijah Egene

calebelijah.egene@ugent.be

1 Department of Green Chemistry and Technology, Faculty of Bioscience Engineering, Ghent University, Coupure Links 653, 9000 Ghent, Belgium

2 Wageningen Environmental Research, Wageningen University and Research, PO Box 47, 6700AA Wageningen, The Netherlands

3 Gruppo Ricicla, Dipartimento di Science Agrarie e Ambientali: Produzione, Territorio, Agroenergia, Università degli Studi di Milano, Via Celoria 2, 20133 Milano, Italy

4 Department of Environment, Faculty of Bioscience Engineering, Ghent University, Coupure Links 653, 9000 Ghent, Belgium has encouraged a rapid increase of anaerobic digestion (AD) installations. The number of $\mathrm{AD}$ installations in the $\mathrm{EU}$ rose from 6227 to 17,662 between 2009 and 2016 (EBA 2018), with a main focus on $\mathrm{AD}$ of residues from food and feed industries, sewage sludge, animal manure, and landfill waste. While biogas is the primary product from $\mathrm{AD}$, millions of tonnes of digestate are generated annually as a by-product. Digestate requires appropriate management or disposal to prevent overfertilisation in regions with an excess of manure and digestate as well as storage problems. Digestate is typically separated mechanically into liquid and solid fractions as a simple procedure to overcome transport constraints and facilitate application to soil (Holm-Nielsen et al. 2009). The liquid fraction (LF) typically contains a significant amount of nitrogen $(\mathrm{N})$, mainly in the form of plant available ammonium-N, and can be used as a N-fertiliser (Sigurnjak et al. 2017). The solid fraction (SF), on the other hand, has a high dry matter content, is rich in phosphorus $(\mathrm{P})$ and organic carbon $(\mathrm{C})$, and has the potential to be used as a $\mathrm{P}$ fertiliser and an organic soil improver. 
The recently approved Fertiliser Regulation (European Commission 2019) makes a distinction between "organic soil improvers" and "solid organic fertilisers" primarily based on the nutrient content and the intended use of the biosolid. While solid organic fertilisers are added as sources of readily available plant nutrients, organic soil improvers are added primarily as sources of organic matter (OM) in order to ameliorate soil physicochemical and biological properties. When OM is added to soil, microorganisms use it as a source of energy thereby emitting $\mathrm{CO}_{2}$ via respiration (Juma 1999). Hence, only the fraction of $\mathrm{OM}$ that is less degradable remains and eventually contributes to soil organic matter. This stable fraction of the original OM that remains after 1 year is often referred to as the "effective organic matter" (EOM) (Veeken et al. 2017). In order to be classified as an organic soil improver, Veeken et al. (2017) proposed that the EOM to mineral-N ratio must be higher than 150 and the EOM to phosphate $\left(\mathrm{P}_{2} \mathrm{O}_{5}\right)$ ratio must be higher than 35 .

$\mathrm{SFs}$ from $\mathrm{AD}$ processing have high $\mathrm{C}$ and $\mathrm{P}$ contents, and so the $\mathrm{C} / \mathrm{P}$ ratio may be problematic for their application as soil improvers in regions with restrictions on $\mathrm{P}$ input (e.g. Belgium and The Netherlands). These SFs are marketed in other countries as P-fertilisers, thus, representing a loss of organic $\mathrm{C}$ from such regions. A recent study has shown that up to $80 \% \mathrm{P}$ can be recovered from SFs of digestate at reasonable costs using a P-stripper system known as Re-P-eat (Schoumans et al. 2017). This process involves addition of sulphuric acid to release the phosphate from the SF followed by adding a base to precipitate the solubilised $\mathrm{P}$. Two products are then obtained - a mainly crystalline struvite $\left(\mathrm{NH}_{4} \mathrm{MgPO}_{4}\right.$. $6 \mathrm{H}_{2} \mathrm{O}$ ) and a P-POOR SF (Regelink et al. 2019; Schoumans et al. 2017). While the recovered struvite can be sold as a $P$ fertiliser, the P-POOR SF may open opportunities for keeping $\mathrm{C}$ in regions with $\mathrm{P}$-rich soils.

Sustaining an adequate soil organic matter content plays an important role in maintaining and improving soil microbial health and soil structure, which is crucial for attaining sustainable crop production (Chatterjee et al. 2017). Moreover, European policy has recognised soil organic carbon (SOC) as an instrument to reduce $\mathrm{CO}_{2}$ emission through soil $\mathrm{C}$ sequestration (Lugato et al. 2014). Finally, organic soil improvers have also proven their potential utilisation to reduce metal mobility in soils exhibiting elevated concentrations, and by doing so alleviate associated environmental risks (Van Poucke et al. 2020; Egene et al. 2018). Therefore, there is a need for increased utilisation of $\mathrm{C}$-rich biosolids in agriculture to improve soil organic matter and increase soil $\mathrm{C}$ reserves.

There are a few studies that have looked at the $\mathrm{C}$ and $\mathrm{N}$ mineralisation potential of digestates in soils (Peters and Jensen 2011; de la Fuente et al. 2013; Möller 2015). These studies highlighted the relationships between digestate composition and $\mathrm{C}$ and $\mathrm{N}$ mineralisation dynamics. However, the effect of P-stripping of SFs of digestates on its OM decomposition and consequent $\mathrm{C}$ and $\mathrm{N}$ mineralisation has not been investigated. This makes it necessary to assess the dynamics of active $\mathrm{C}$ and $\mathrm{N}$ pools in the SFs of digestate to determine how much organic $\mathrm{C}$ and $\mathrm{N}$ will mineralise in current and future growing seasons. The aim of this study was to evaluate the dynamics of $\mathrm{C}$ - and $\mathrm{N}$-mineralisation in soil amended with SFs of digestate following different postdigestion treatments, compared with conventional organic amendments (compost and biochar), in order to quantify the mineralisable $\mathrm{C}$ and $\mathrm{N}$. To achieve this, the $\mathrm{C}$ and $\mathrm{N}$ decomposition kinetics of the different biosolids were studied through incubation experiments and related to some of their inherent agrochemical characteristics (e.g. $\mathrm{C} / \mathrm{N}$ ratio, mineral $\mathrm{N}, \mathrm{pH}$ ). Any such relationships should provide useful insight into the soil improving properties of SF of digestate and may be useful in estimating appropriate application rates. Furthermore, the potential of long-term application of the SFs as sources of soil organic matter in P-rich soils was evaluated.

\section{Materials and methods}

\subsection{Biosolid collection and characterisation}

Six biosolids (Table 1) were used: four SFs that went through different post-digestion treatment steps, biochar, and compost. All SFs were collected in 2018 from full-scale AD installations of either Groot Zevert Vergisting (GZV) (Beltrum, The Netherlands) or AM Power (Pittem, Belgium). Briefly, the AD plant of AM Power has a total utilisable volume of $20,000 \mathrm{~m}^{3}$ producing 7360 and $7435 \mathrm{kWh}$ day $^{-1}$ of thermal and electrical energy, respectively, by the anaerobic digestion of organic biological waste. GZV is an AD plant with a volumetric capacity of $15,000 \mathrm{~m}^{3}$ producing $10 \mathrm{Mm}^{3}$ of biogas by mesophilic digestion of animal manure (74\%) and various organic waste products from the agro-food industry plus glycerin $(26 \%)$ as co-substrates.

In this study, the SFs are differentiated primarily based on the type of post-digestion treatment(s) of the digestates. The digestate from AM Power underwent solid-liquid separation with a decanter centrifuge after which the SF was passed through a fluidised bed dryer at $60{ }^{\circ} \mathrm{C}$ to obtain a dried SF denoted as DRY-SF. Three SFs were obtained from the digestate of GZV: (i) SF separated by a decanter centrifuge (DEC-SF), (ii) SF separated by a screw press (SCP-SF), and (iii) SF separated by a decanter centrifuge followed by $\mathrm{P}$ stripping (P-POOR SF). The P-stripping process, called ReP-eat, was developed by Wageningen UR and has been demonstrated at pilot scale (Schoumans et al. 2017). The process involves acidifying $\left(\mathrm{H}_{2} \mathrm{SO}_{4}\right)$ the $\mathrm{SF}$ of digestate to $\mathrm{pH} 5$ to solubilise mineral $\mathrm{P}$ followed by the solid-liquid separation of the acid slurry to obtain a P-rich acid solution and a P-poor SF. 
Table 1 Description of the studied organic materials

\begin{tabular}{lllll}
\hline Biosolid & Name & Feedstock & Post-digestion treatment at AD plant \\
\cline { 3 - 5 } & & & Solid-liquid separation & Additional treatment \\
\hline DEC-SF & Solid fraction & $74 \%$ pig manure and 26\% co-substrates & Decanter centrifuge & - \\
SCP-SF & Solid fraction & $74 \%$ pig manure and 26\% co-substrates & Screw press & - \\
P-POOR SF & Solid fraction & $74 \%$ pig manure and 26\% co-substrates & Decanter centrifuge & P stripping (Re-P-eat) \\
DRY-SF & Solid fraction & Organic biological waste & Decanter centrifuge & Drying at $~ 60{ }^{\circ} \mathrm{C}$ \\
COMP & Commercial compost & Source-separated household and garden waste & & Pyrolysis at $400{ }^{\circ} \mathrm{C}$ \\
BCHR & Biochar & P-POOR SF & - & \\
\hline
\end{tabular}

$D E C-S F$ solid fraction after decanter, $S C P-S F$ solid fraction after screw press, $P$ - $P O O R S F$ solid fraction decanter and $\mathrm{P}$ stripping, $D R Y-S F$ solid fraction after decanter and drying, $C O M P$ compost, $B C H R$ biochar produced from P-POOR SF

$\mathrm{Ca}(\mathrm{OH})_{2}$ or $\mathrm{Mg}(\mathrm{OH})_{2}$ is then added to the acid solution to precipitate the $\mathrm{P}$ as calcium phosphate or struvite (Schoumans et al. 2017).

Biochar (BCHR) was produced via slow pyrolysis of the $\mathrm{P}$ POOR SF at $400{ }^{\circ} \mathrm{C}$ and was included in the study. In addition, commercial compost (COMP) produced by Attero (Venlo, The Netherlands) from source-separated household and garden waste was used as reference material.

All biosolids were collected in polyethylene sampling bottles and stored at $4{ }^{\circ} \mathrm{C}$ until the start of the incubation experiments. The dry matter (DM) content was determined by drying to constant weight $(48 \mathrm{~h})$ at $80{ }^{\circ} \mathrm{C}$ and was calculated as percentage of wet weight. OM was measured based on losson-Ignition (LOI) of dried solids by incineration at $550^{\circ} \mathrm{C}$ in a muffle furnace for $4 \mathrm{~h}$. The $\mathrm{pH}$ and electrical conductivity (EC) were measured potentiometrically using an Orion520A pH-meter and a WTW-LF537 (GE) conductivity electrode, respectively, in a 1:5 $\left(\mathrm{w} \mathrm{w}^{-1}\right)$ wet solids to deionised water ratio. Total OC, N, and sulphur (S) were determined via Elemental analysis (Variomax CNS analyzer, Elementar, Germany). Ammonium $\left(\mathrm{NH}_{4}{ }^{+}-\mathrm{N}\right)$ and nitrate $\left(\mathrm{NO}_{3}{ }^{-} \mathrm{N}\right)$ were analysed in a 1:10 ( $\left.\mathrm{w} \mathrm{w}^{-1}\right)$ suspension of wet solid and $1 \mathrm{M}$ $\mathrm{KCl}$ shaken end-over-end for $30 \mathrm{~min}$. The extracts were filtered (Whatman No. 45) and analysed for their $\mathrm{NH}_{4}{ }^{+}-\mathrm{N}$ and $\mathrm{NO}_{3}{ }^{-}-\mathrm{N}$ contents with a continuous flow auto-analyser (Chemlab System 4, Skalar, The Netherlands). Total P, potassium $(\mathrm{K})$, calcium $(\mathrm{Ca})$, magnesium $(\mathrm{Mg})$, and sodium $(\mathrm{Na})$ were determined using an inductively coupled plasma emission spectrometry (ICP-OES) (Varian Vista MPX, USA) after wet digestion of the incinerated solids with $5 \mathrm{ml}$ of $6 \mathrm{M} \mathrm{HNO}_{3}$ and $5 \mathrm{ml}$ of $3 \mathrm{M} \mathrm{HNO}_{3}$ at $150{ }^{\circ} \mathrm{C}$ (Van Ranst et al. 1999). Water soluble carbon (WSC) and hot water extractable carbon (HWEC) were determined on fresh samples according to a modified method of Ghani et al. (2003). For WSC, $3 \mathrm{~g}$ of each biosolid and $30 \mathrm{ml}$ of distilled water was weighed into $50 \mathrm{ml}$ polypropylene centrifuge tubes, which were shaken end-overend for $30 \mathrm{~min}$. The tubes were centrifuged for $20 \mathrm{~min}$ at $3500 \mathrm{rpm}$, and the supernatants were filtered (Whatman No.
45), and transferred into vials for $\mathrm{C}$ analysis. To determine the HWEC, $30 \mathrm{ml}$ of distilled water was added to the residues from the previous step, shaken briefly to re-suspend the solids, capped well, and placed in a hot water bath at $80^{\circ} \mathrm{C}$ for $16 \mathrm{~h}$. The extracts were centrifuged for $20 \mathrm{~min}$ at $3500 \mathrm{rpm}$, filtered (Whatman No. 45), and transferred into vials for $\mathrm{C}$ analysis. Total $\mathrm{C}$ (inorganic and organic $\mathrm{C}$ ), in both the first and second extracts, was determined using a TOC-analyser (TOC-5000, Shimadzu, Tokyo Japan).

\subsection{Soil characteristics}

Soil for the incubation experiments was taken from the topsoil layer $(0-30 \mathrm{~cm})$ of an unfertilised agricultural field in Evergem (Belgium). The soil texture was sandy-loam (87\% sand, $8.5 \%$ silt, and $4.5 \%$ clay), with a $\mathrm{pH}-\mathrm{H}_{2} \mathrm{O}$ of 7.1 , initial $\mathrm{C}$ content of $118 \mathrm{mg} \mathrm{kg}^{-1}$, and an initial exchangeable $\mathrm{N}$ content of $1.7 \mathrm{mg} \mathrm{NH}_{4}^{+}-\mathrm{N} \mathrm{kg}^{-1}$ and $21 \mathrm{mg} \mathrm{NO}_{3}^{-}-\mathrm{N} \mathrm{kg}^{-1}$. Prior to incubations, the soil was air-dried and sieved through a 2-mm screen.

\subsection{C incubation experiment}

The $\mathrm{C}$ and $\mathrm{N}$ mineralisation experiments were done independently due to their distinct experimental protocols. Organic $\mathrm{C}$ mineralisation was evaluated by measurement of soil $\mathrm{CO}_{2}$ respiration (De Neve and Hofman 2000). First, the soil was wetted with distilled water to attain a moisture content corresponding to a $50 \%$ water filled pore space (WFPS), taking into account the moisture content of the air-dried soil and tested organic materials. The tested organic materials were mixed with $117 \mathrm{~g}$ of soil at an application rate of $9000 \mathrm{~kg} \mathrm{TOC} \mathrm{ha}^{-1}$ (or $3 \mathrm{~g}$ TOC $\mathrm{kg}$ soil $\left.^{-1}\right)$. These mixtures were filled into PVC tubes $(7.2 \mathrm{~cm}$ height, $6.8 \mathrm{~cm}$ diameter) and gradually compacted during filling to attain an apparent bulk density of $1.4 \mathrm{~g} \mathrm{~cm}^{-3}$. The conversion from $\mathrm{kg} \mathrm{ha}^{-1}$ to $\mathrm{g} \mathrm{kg}^{-1}$ soil was based on the surface area of the tubes. The percentage of WFPS in the soil was calculated from the equation (Linn and Doran 1984): 
$\mathrm{WFPS} \%=(\mathrm{GWC} \times \mathrm{BD}) /(1-(\mathrm{BD} / \mathrm{PD})) \times 100$

where GWC is the gravimetric water content ( $\mathrm{g}$ water $\mathrm{g}$ soil $\left.{ }^{-1}\right)$, $\mathrm{BD}$ is the dry bulk density $\left(\mathrm{Mg} \mathrm{m}^{-3}\right)$, and PD is the particle density $\left(\mathrm{Mg} \mathrm{m}^{-3}\right)$.The PVC tubes containing the soil-biosolid mixtures were placed in 1-L Mason jars, and just before closing them airtight, glass vials containing $15 \mathrm{ml} 1 \mathrm{M} \mathrm{NaOH}$ were placed to capture $\mathrm{CO}_{2}$ evolved. Controls were performed without soil samples and with unamended soil. The incubation was done under controlled conditions at $10{ }^{\circ} \mathrm{C}$ for 81 days. At predetermined sampling times $(1,2,3,5,9,14,21,28,36,45$, 59 , and 81 days), the glass vials were removed for determination of amounts of evolved $\mathrm{CO}_{2}$ by titration of the $\mathrm{NaOH}$ with $1 \mathrm{M}$ $\mathrm{HCl}$ after precipitation of carbonates with excess $\mathrm{BaCl}_{2}$ (Anderson 1982). During each sampling time, moisture was adjusted to 50\% WFPS and the jars were left opened for at least $2 \mathrm{~h}$ to allow replenishment of oxygen.

\section{4 $\mathrm{N}$ incubation experiment}

The evolution of $\mathrm{N}$ mineralisation was determined by measuring temporal changes in the mineral $\mathrm{N}\left(\mathrm{NH}_{4}{ }^{+}-\mathrm{N}_{\text {and }} \mathrm{NO}_{3}{ }^{-} \mathrm{N}\right)$. The air-dried and sieved soil was brought to $35 \%$ of WFPS and was pre-incubated at $21.5^{\circ} \mathrm{C}$ for 1 week. This step was performed to stabilise the microbial community in the soil. After pre-incubation, each of the biosolids was applied at a rate of $9000 \mathrm{~kg} \mathrm{TOC} \mathrm{ha}{ }^{-1}$ (as in the C incubation) and thoroughly mixed with approximately $272 \mathrm{~g}$ of pre-incubated soil. Table 2 shows the corresponding total $\mathrm{N}$, organic $\mathrm{N}$, and mineral $\mathrm{N}$ dosages. The soil-biosolid mixtures were placed in PVC tubes (18.2-cm height, $4.61-\mathrm{cm}$ diameter) at a bulk density of $1.4 \mathrm{~g} \mathrm{~cm}^{-3}$ and the WFPS in the tubes was brought up to $50 \%$ by adding distilled water. In total, 256 PVC tubes ( 8 treatments $\times 4$ replicates $\times 8$ sampling times) were covered with pin-holed gas permeable parafilm, placed on trays in completely randomised design (CRD) and incubated at 21.5 ${ }^{\circ} \mathrm{C}$ for 112 days. Destructive sampling was done bi-weekly in

Table 2 Dosages in $\mathrm{kg} \mathrm{ha}^{-1}$ for total organic carbon (TOC), total $\mathrm{N}$ $\left(N_{\text {tot }}\right)$, organic $\mathrm{N}\left(N_{\text {org }}\right)$, and mineral $\mathrm{N}\left(N_{\text {min }}\right)$ of the tested biosolids as implied in the $\mathrm{C}$ incubation and $\mathrm{N}$ mineralisation experiment

\begin{tabular}{lllll}
\hline Biosolid & TOC & $N_{\text {tot }}$ & $N_{\text {org }}$ & $N_{\text {min }}$ \\
\hline DEC-SF & 9000 & 500 & 306 & 194 \\
SCP-SF & 9000 & 252 & 118 & 134 \\
P-POOR SF & 9000 & 309 & 283 & 26 \\
DRY-SF & 9000 & 983 & 763 & 220 \\
COMP & 9000 & 788 & 776 & 12 \\
BCHR & 9000 & 316 & 316 & 0.42 \\
\hline
\end{tabular}

$D E C-S F$ solid fraction after decanter, $S C P-S F$ : solid fraction after screw press, $P$-POOR $S F$ solid fraction decanter and $\mathrm{P}$ stripping, $D R Y-S F$ solid fraction after decanter and drying, COMP compost, $B C H R$ biochar produced from P-POOR SF which 32 intact tubes ( 4 treatments $\times 4$ replicates) were removed. After mixing well, $10 \mathrm{~g}$ of soil per tube was analysed for its mineral $\mathrm{N}$ contents as described in Section 2.1. The sum of soil $\mathrm{NH}_{4}{ }^{+}-\mathrm{N}$ and $\mathrm{NO}_{3}{ }^{-}-\mathrm{N}$ build-up in excess to the unamended soil was considered as the amount of $\mathrm{N}$ mineralised per sampling time.

\subsection{Data and statistical analysis}

The cumulative amount of mineralised $\mathrm{C}$, evolved as $\mathrm{CO}_{2}$ (cumulative \% $\mathrm{C}$ mineralised) from each of the tested biosolids, was calculated as the difference between the cumulative $\mathrm{CO}_{2}$-C evolved from the unamended (control) soil and the biosolid-treated soil. Cumulative amounts of mineralised $\mathrm{C}$ were expressed as a percentage of the amount of TOC applied (Eq. 2) and is hereafter referred to as $\% C$ mineralised $\left(\% C_{\text {min }}\right)$.

$\% C_{\min }=\frac{\left(C \min _{\text {,reatment }}-C \min _{, \text {control }}\right)}{\text { TOC applied }} \times 100$

A second-order kinetic model was fitted to the $\% C_{\min }$ data for each of the tested biosolid using the Grapher Statistical software (Version 10). The second-order kinetic model (Eq. 3 ) suggests that the mineralisation or decomposition is proportional to the product of the substrate concentrations and of the microorganisms derived from the substrate (Sleutel et al. 2005) and is expressed by

$C(t)=C_{A}-\frac{C_{A}}{1+k_{2} a(1-\mathrm{a}) C_{A} \mathrm{t}}$

Where $C(t)$ is the cumulative amount of $\mathrm{C}$ mineralised at time $t, C_{A}$ is the amount of mineralisable $\mathrm{C}, a$ is the fraction of decomposed substrate that becomes part of microbial biomass, and $k_{2}$ is the second order C-mineralisation rate constant. As a simplification, $k_{2}$ and $a$ were determined together as a single variable $k_{2} a(1-a)$. The model parameters were then used to extrapolate the stable organic fraction left in the soil after a period of 365 days (i.e. the humification coefficient).

Net $\mathrm{N}$ mineralisation (Eq. 4) in the biosolid-amended treatments and unamended control was calculated by subtracting the mineral $\mathrm{N}\left(N_{\min }\right)$ content of the treatment at day 0 from the $N_{\min }$ in the sample at all subsequent measurements and expressed as percentage of organic $\mathrm{N}\left(N_{\text {org }}\right)$ and total $\mathrm{N}$ $\left(N_{\text {tot }}\right)$, as follows:

$$
\begin{gathered}
N \text { et mineralisation : } \mathrm{t} \text {; \%organic } \mathrm{N})=\frac{N_{\min }(t=x)-N_{\min }(t=0)}{N_{\text {org }}} \\
(t ; \% \text { total } \mathrm{N})=\frac{N_{\min }(t=x)-N_{\min }(t=0)}{N_{\text {tot }}}
\end{gathered}
$$


Treatment effects were compared using one-way ANOVA and the Tukey's honestly significant difference (HSD) test. Pearson's correlation analysis was performed to test relationships between variables. All tests were carried out at a probability $(P)$ level of 0.05 using SPSS 22.0 software for Windows.

\section{Results}

\subsection{Biosolid characteristics}

The agrochemical characteristics of the tested biosolids are summarised in Table 3. With the exception of P-POOR SF, the $\mathrm{pH}$ of the tested biosolids were alkaline (7.3-8.5) which is consistent with previously reported $\mathrm{pH}$ values of digestate and digestate products (Alburquerque et al. 2012; Pognani et al. 2009). The acidic $\mathrm{pH}$ of the P-POOR SF (5.7) was attributed to the P-stripping process that involved the addition of acid $\left(\mathrm{H}_{2} \mathrm{SO}_{4}\right)$. Pyrolysis of the P-POOR SF to produce BCHR greatly altered its agrochemical properties with a noticeably higher $\mathrm{pH}$, total carbon (TOC), and total nitrogen (TN) contents (Table 3).
TOC, TN, and inorganic $\mathrm{N}$ content in the solid fractions were variable. DRY-SF had the highest TOC $\left(275 \mathrm{~g} \mathrm{~kg}^{-1}\right)$ and TN (30 $\left.\mathrm{g} \mathrm{kg}^{-1}\right)$, while DEC-SF had the lowest TOC (102 $\left.\mathrm{g} \mathrm{kg}^{-1}\right)$ and SCP-SF the lowest TN $\left(5.0 \mathrm{~g} \mathrm{~kg}^{-1}\right)$. This variability is reflected in the $C / N_{\text {tot }}$ ratios which ranged between 9.2 and 36 (Table 3 ). The tested biosolids were generally characterised by very low amounts of $\mathrm{NO}_{3}{ }^{-} \mathrm{N}$. The $\mathrm{NH}_{4}{ }^{+}-\mathrm{N} / \mathrm{TN}$ ratio, which provides an indication of the amount of readily plant-available $\mathrm{N}$, was low in all the tested biosolids. It was lowest in DRY-SF and BCHR due to drying and pyrolysis, respectively, which are processes that result in a significant loss of $\mathrm{NH}_{4}$.

Moderate amounts of TN were present in the SFs, mostly in the form of organic $\mathrm{N}$, as could be expected since the solidliquid separation of digestate concentrates the major part of the mineral $\mathrm{N}$ in the LF. In general, their OM and $\mathrm{N}$ contents did not show much variability (74-89\% OM, 5.0-5.7 $\mathrm{g} \mathrm{kg}^{-1}$ $\mathrm{TN})$. However, high variability was observed in the total $\mathrm{P}$ content with DEC-SF having 1.7 and 5 times more $\mathrm{P}$ than SCP-SF and P-POOR SF, respectively. DRY-SF was characterised by a relatively low OM content (59\%) and a higher concentration of nutrients, including $\mathrm{TN}$ $\left(30 \mathrm{~g} \mathrm{~kg}^{-1}\right)$ and TP $\left(14 \mathrm{~g} \mathrm{~kg}^{-1}\right)$, compared with the other SFs.

Table 3 Agrochemical characteristics of the tested organic materials ( $n=3 \pm$ standard deviation)

\begin{tabular}{|c|c|c|c|c|c|c|}
\hline Parameter & DEC-SF & SCP-SF & P-POOR SF & DRY-SF & COMP & $\mathrm{BCHR}$ \\
\hline $\mathrm{pH}$ & $8.4 \pm 0.1$ & $8.5 \pm 0.0$ & $5.7 \pm 0.0$ & $7.8 \pm 0.1$ & $8.5 \pm 0.0$ & $7.3 \pm 0.0$ \\
\hline $\mathrm{EC}\left(\mathrm{mS} \mathrm{cm}^{-1}\right)$ & $2.4 \pm 0.2$ & $1.1 \pm 0.0$ & $1.4 \pm 0.0$ & $6.1 \pm 0.0$ & $0.7 \pm 0.0$ & $2.8 \pm 0.0$ \\
\hline $\mathrm{DM}(\%)$ & $25 \pm 0.6$ & $37 \pm 0.4$ & $34 \pm 0.1$ & $84 \pm 0.7$ & $54 \pm 0.4$ & $98 \pm 0.2$ \\
\hline $\mathrm{OM}(\%$ of $\mathrm{DM})$ & $74 \pm 2.9$ & $89 \pm 0.2$ & $89 \pm 0.1$ & $59 \pm 1.5$ & $30 \pm 0.8$ & $75 \pm 0.0$ \\
\hline TOC $\left(\mathrm{g} \mathrm{kg}^{-1}\right)$ & $102 \pm 4.0$ & $177 \pm 2.2$ & $161 \pm 0.9$ & $275 \pm 4.3$ & $70 \pm 2.5$ & $643 \pm 0.2$ \\
\hline WSC (\% of TOC) & $1.7 \pm 0.0$ & $0.9 \pm 0.1$ & $0.3 \pm 0.0$ & $0.8 \pm 0.1$ & $1.7 \pm 0.1$ & $0.04 \pm 0.0$ \\
\hline HWEC (\% of TOC) & $3.0 \pm 0.3$ & $1.0 \pm 0.1$ & $0.6 \pm 0.0$ & $1.2 \pm 0.0$ & $4.3 \pm 0.2$ & $0.05 \pm 0.0$ \\
\hline$N_{\text {tot }}\left(\mathrm{g} \mathrm{kg}^{-1}\right)$ & $5.7 \pm 0.1$ & $5.0 \pm 0.1$ & $5.5 \pm 0.2$ & $30 \pm 0.1$ & $6.1 \pm 0.2$ & $23 \pm 0.1$ \\
\hline \multicolumn{7}{|l|}{$N_{\min }\left(\mathrm{g} \mathrm{kg}^{-1}\right)$} \\
\hline $\mathrm{NH}_{4}^{+}-\mathrm{N}$ & $2.2 \pm 0.1$ & $2.7 \pm 0.0$ & $0.46 \pm 0.0$ & $2.0 \pm 0.0$ & $0.22 \pm 0.0$ & $0.03 \pm 0.0$ \\
\hline $\mathrm{NO}_{3}{ }^{-}-\mathrm{N}$ & $0.002 \pm 0.0$ & $0.003 \pm 0.0$ & $0.001 \pm 0.0$ & $0.1 \pm 0.0$ & $0.01 \pm 0.0$ & $0.001 \pm 0.0$ \\
\hline$C / N_{\text {tot }}$ & 18 & 36 & 29 & 9.2 & 11 & 28 \\
\hline$C / N_{\text {org }}$ & 29 & 76 & 32 & 9.8 & 12 & 28 \\
\hline$N_{\min } / N_{\text {tot }}(\%)$ & 39 & 54 & 8.0 & 7.0 & 2.0 & 0.0 \\
\hline \multicolumn{7}{|l|}{ Elements $\left(\mathrm{g} \mathrm{kg}^{-1}\right)$} \\
\hline $\mathrm{P}$ & $5.6 \pm 0.2$ & $3.3 \pm 0.1$ & $1.1 \pm 0.0$ & $14 \pm 1.1$ & $1.7 \pm 0.2$ & $3.1 \pm 0.2$ \\
\hline $\mathrm{Ca}$ & $5.8 \pm 0.8$ & $4.1 \pm 0.4$ & $3.4 \pm 0.6$ & $18 \pm 1.1$ & $12 \pm 0.8$ & $12 \pm 1.0$ \\
\hline $\mathrm{Mg}$ & $3.5 \pm 0.5$ & $1.7 \pm 0.3$ & $0.7 \pm 0.2$ & $3.5 \pm 0.2$ & $1.7 \pm 0.1$ & $9.1 \pm 1.2$ \\
\hline $\mathrm{K}$ & $3.2 \pm 0.3$ & $2.3 \pm 0.2$ & $0.8 \pm 0.0$ & $9.2 \pm 0.7$ & $2.4 \pm 0.1$ & $11 \pm 0.2$ \\
\hline $\mathrm{Al}$ & $0.93 \pm 0.1$ & $0.34 \pm 0.1$ & $0.35 \pm 0.0$ & $2.8 \pm 0.2$ & $3.2 \pm 0.4$ & $1.6 \pm 0.0$ \\
\hline
\end{tabular}

$E C$ electrical conductivity, $D M$ dry matter, $O M$ organic matter, $T O C$ total organic carbon, WSC water soluble carbon, $H W E C$ hot water extractable carbon, $N_{\text {tot }}$ total nitrogen, $N_{\text {min }}$ mineral nitrogen, $N_{\text {org }}$ organic nitrogen, $D E C-S F$ solid fraction after decanter, $S C P-S F$ solid fraction after screw press, $P$ $P O O R S F$ solid fraction decanter and $\mathrm{P}$ stripping, $D R Y-S F$ solid fraction after decanter and drying, COMP compost, $B C H R$ biochar produced from $\mathrm{P}$ POOR SF 
The WSC and HWEC, which have been reported to constitute the highly labile pool of $\mathrm{C}$ in organic materials (Ghani et al. 2003; Weigel et al. 2011), represented $<2 \%$ and $\leq 3 \%$, respectively, of the total $\mathrm{C}$ in all the tested biosolids. This suggests that majority of the $\mathrm{C}$ in the biosolids was present as the stable carbon fraction.

\subsection{C mineralisation}

The $C_{\min }$ of the tested biosolids was calculated according to Eq. 2. The results were expressed in terms of the percentage of $\mathrm{C}$ added, and mineralisation curves were plotted (Fig. 1). At the end of the incubation period, the highest $C_{\min }$ was observed in SCP-SF (23\%) at a 5\% significance level. The $C_{\text {min }}$ of DEC-SF, DRY-SF, and P-POOR SF did not significantly $(P<0.05)$ differ from each other but were significantly higher than in COMP (6\%) and BCHR (4\%). In general, the curves indicate that the mineralisation of the SFs followed similar patterns that clearly differed from the compost and biochar treatments.

The $\% C_{\min }$ curves for the different biosolids were fitted to a second-order kinetic model (Eq. 3) with high coefficients of determination (Table 4). The amount of mineralisable $\mathrm{C}\left(C_{A}\right)$ was followed the same pattern of $C_{\text {min }}$ : SCP-SF $>$ DEC-SF $>$ P-POOR SF $>$ DRY-SF $>$ BCHR $>$ COMP. Humification coefficients (HC), which is defined as the percentage of OC that remains after 1 year, was calculated for each biosolid using the second order kinetic model. Among the SFs, SCPSF had the lowest $\mathrm{HC}(51 \%)$ which indicates that it contained the least stable forms of OC, while other SFs contained the

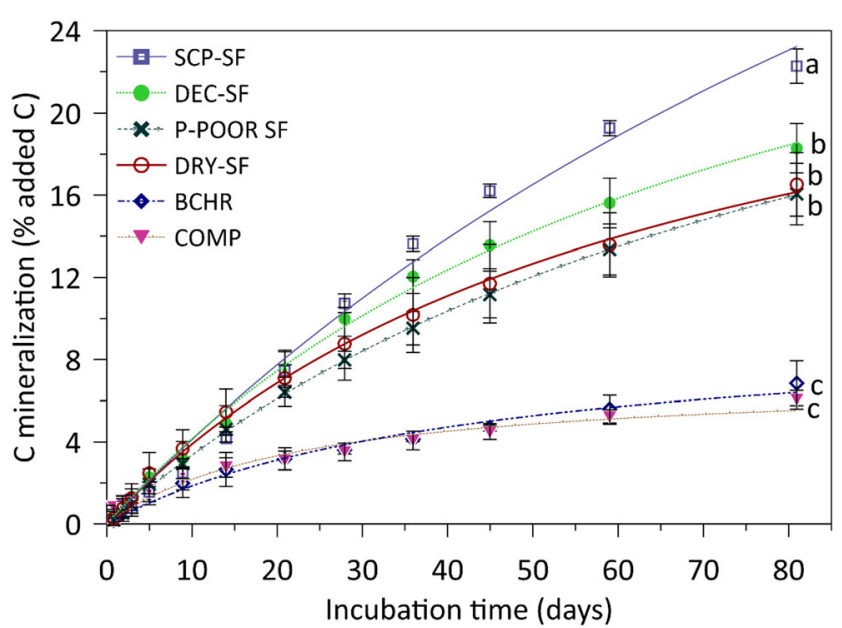

Fig. 1 Cumulative amount of $\mathrm{C}$ mineralised after addition of $9000 \mathrm{~kg} \mathrm{OC} \mathrm{ha}{ }^{-1}$ to soil during the 81-day incubation period at $10^{\circ} \mathrm{C}$ (mean value \pm standard deviation, $n=3$ ). Lines represent the curve-fitting result; symbols are experimental data. Different lower case letters indicate significant differences between $\mathrm{C}$ mineralisation means at day 81. DECSF solid fraction after decanter, SCP-SF solid fraction after screw press, P-POOR SF solid fraction decanter and P stripping, DRY-SF solid fraction after decanter and drying, COMP compost, BCHR biochar produced from P-POOR SF more stable forms of OC with HCs between 70 and 75 (Table 4). The variation in HC may be explained by differences in $C_{A}$ in the tested biosolids which showed a positive linear relationship between $\mathrm{HC}$ and $C_{A}(r=0.99, P<0.05)$. The HC of compost in this study (93\%) was in agreement with values (95 and 93\%) reported by De Neve et al. (2003) and Postma and Ros (2016), respectively. Table 6 shows that HC was positively correlated with $N_{\text {org }} / N_{\text {tot }}$ ratio $(r=0.82$, $P<0.05)$ and negatively correlated with $N_{\min } / N_{\text {tot }}$ ratio $(r=$ $-0.82, P<0.05)$.

\subsection{Estimating carbon retention potential}

The humification coefficients (HC) can be expressed in kilogram per megagram of DM to derive the effective organic matter (EOM), which is defined as the OM that is left in the soil after 365 days (Veeken et al. 2017). Among the solid digestates tested, the highest EOM calculated was in DRY$\mathrm{SF}$ at $369 \mathrm{~kg} \mathrm{Mg}^{-1}$ (Table 5). This means that after an initial application of $1 \mathrm{Mg}$ of biosolid, $369 \mathrm{~kg}$ of OM will remain in the soil after 1 year.

The OM/P ratio which gives an indication of the quantity of biosolid that can be applied within $\mathrm{P}$ limits was also determined (Table 5). DRY-SF had an OM/P ratio of $36 \mathrm{~kg} \mathrm{~kg}^{-1}$, of which $27 \mathrm{~kg} \mathrm{~kg}^{-1}$ was EOM. For the P-POOR SF instead, the $\mathrm{EOM} / \mathrm{P}$ ratio was $204 \mathrm{~kg} \mathrm{~kg}^{-1}$, meaning that 7.5 times more EOM per kg of added $\mathrm{P}$ can be applied to soil as compared with DRY-SF.

\subsection{N-mineralisation}

At the start of the incubation, the mineral $\mathrm{N}$ in all treatments was present mainly as $\mathrm{NH}_{4}{ }^{+}-\mathrm{N}$ (Fig. 2a). However, by the 14th day, majority of the $\mathrm{NH}_{4}{ }^{+}-\mathrm{N}$ was already nitrified (Fig. 2b). $\mathrm{NO}_{3}{ }^{-}-\mathrm{N}$ increased steadily throughout the duration of the incubation and was highest in DRY-SF and DEC-SF with 129 and $113 \mathrm{mg} \mathrm{kg}^{-1}$, respectively after day 112 . The pattern of total mineral $\mathrm{N}$ evolution and that of $\mathrm{NO}_{3}{ }^{-} \mathrm{N}$ were similar since increases in $\mathrm{NH}_{4}{ }^{+}-\mathrm{N}$ concentration were negligible.

$\mathrm{N}$ mineralisation was calculated as a percentage of the $N_{\text {org }}$ present in the tested biosolid (Fig. 3). N immobilisation occurred in BCHR, P-POOR SF, and SCP-SF, while DEC-SF, DRY-SF, and COMP yielded modest near-linear N mineralisation patterns during the incubation, with the highest $N_{\text {org }}$ mineralisation of $28 \%$ (in DEC-SF). $\mathrm{N}$ is more likely to be net mineralised from substrates with low $\mathrm{C} / \mathrm{N}$ ratio, while substrates with $\mathrm{C} / \mathrm{N}$ ratio $>20$ tend to cause net $\mathrm{N}$ immobilisation in soil (Mendham et al. 2004; Muhammad et al. 2011; Nicolardot et al. 2001; Wagner and Wolf 1999). This was reconfirmed in this study, where $\% \mathrm{~N}_{\text {org }}$ mineralisation and $\mathrm{C} / \mathrm{N}_{\text {tot }}$ ratio were strongly negatively correlated $(r=-0.88$, $P<0.05$ ) (Table 6). The high immobilisation of $\mathrm{N}$ from SCP-SF was likely due to its high $\mathrm{C} / \mathrm{N}_{\text {org }}$ ratio (76) in 
Table 4 Kinetic C-mineralisation parameter values and fit, and humification coefficients $(\mathrm{HC})$ for the tested biosolidsat $10{ }^{\circ} \mathrm{C}$. Parameter data obtained with a second order kinetic model (Eq. 3)

\begin{tabular}{lllllll}
\hline Parameters & DEC-SF & SCP-SF & P-POOR SF & DRY-SF & COMP & BCHR \\
\hline $\mathrm{C}_{\mathrm{A}}$ & 36.27 & 67.44 & 34.29 & 29.05 & 7.065 & 9.793 \\
$\mathrm{~K}_{2} \mathrm{a}(1-a)$ & $3.57 \times 10^{-4}$ & $9.62 \times 10^{-5}$ & $3.16 \times 10^{-4}$ & $5.33 \times 10^{-4}$ & $6.30 \times 10^{-3}$ & $2.38 \times 10^{-3}$ \\
$R^{2}$ & 0.997 & 0.989 & 0.999 & 0.998 & 0.955 & 0.982 \\
$\mathrm{HC}(\%)$ & 70 & 51 & 73 & 75 & 93 & 91 \\
\hline
\end{tabular}

$D E C-S F$ solid fraction after decanter, $S C P-S F$ solid fraction after screw press, $P-P O O R$ SF solid fraction decanter and $\mathrm{P}$ stripping, $D R Y-S F$ solid fraction after decanter and drying, $C O M P$ compost, $B C H R$ biochar produced from P-POOR SF

combination with its high $\mathrm{NH}_{4}{ }^{+}-\mathrm{N}$ that was readily available for fast initial microbial immobilisation (Calderón et al. 2005). P-POOR SF incorporation also induced temporary net $\mathrm{N}$ immobilisation in the first 56 days of incubation, and this may also be attributed to the high $\mathrm{C} / \mathrm{N}_{\text {org }}$ ratio (32) of this biosolid. The mineralisation patterns of SCP-SF and P-POOR SF, however, do suggest a re-mineralisation of the immobilised $\mathrm{N}$.

\section{Discussion}

\subsection{Agrochemical characteristics of tested biosolids}

The high alkalinity of the solid fractions (with the exception of P-POOR SF) may influence soil $\mathrm{pH}$ and nutrient bioavailability when added to soil. For example, nitrification in soil is highest at $\mathrm{pH}$ between 7.5 and 8.0, while ammonification is optimal between $\mathrm{pH} 6.0$ and 8.0 (Wood 1988).

Although DEC-SF, SCP-SF, and P-POOR SF were obtained from digestates derived from the same digested feedstock of GZV (Table 1), they showed a large variation in their total P content. This suggests that the type of post-digestion treatment (i.e. solid-liquid separation technique, P-stripping) may have a stronger influence on $\mathrm{P}$ composition of the SFs than on other nutrient parameters. P-POOR SF not only had the lowest $\mathrm{P}$ content but also the lowest $\mathrm{K}$ concentration. This was because leaching of $\mathrm{P}$ also removes $\mathrm{K}$ due their similar mobility kinetics (Nishanth and Biswas 2008).

The loss of moisture from drying resulted in increased concentration of nutrients in DRY-SF. Although the mineral $\mathrm{N}$ content was low $\left(2.0 \mathrm{~g} \mathrm{~kg}^{-1}\right)$, the high organic $\mathrm{N}$ level may lead to a steady supply of $\mathrm{N}$ to crops provided there would be continuous mineralisation. These characteristics suggest that DRY-SF is more suited for use as a solid organic fertiliser rather than as organic soil improver. Furthermore, its high DM content (84\%) may ease the storage and transportation of the DRY-SF.

There was no significant correlation between either WSC or HWEC and $\% C_{\min }(r=0.11$ and $r=0.25$, respectively; $P<0.05)$. For instance, the WSC and HWEC were highest in compost even though $\% C_{\min }$ in compost was very low. This may be due to the inherent heterogeneity of the feedstocks as well as differences in processing technologies applied. These results suggest that WSC and HWEC may not be

Table 5 Composition of organic fertilising biosolids

\begin{tabular}{|c|c|c|c|c|c|c|}
\hline Parameter & $\begin{array}{l}\text { DEC- } \\
\text { SF }\end{array}$ & $\begin{array}{l}\text { SCP- } \\
\text { SF }\end{array}$ & P-POOR SF & $\begin{array}{l}\text { DRY- } \\
\text { SF }\end{array}$ & COMP & $\mathrm{BCHR}$ \\
\hline $\mathrm{DM}\left(\mathrm{kg} \mathrm{Mg}^{-1}\right)$ & 251 & 365 & 335 & 840 & 535 & 982 \\
\hline $\mathrm{OM}\left(\mathrm{kg} \mathrm{Mg}^{-1}\right)$ & 185 & 324 & 298 & 492 & 160 & 737 \\
\hline $\mathrm{HC}(\%)$ & 70 & 51 & 73 & 75 & 93 & 91 \\
\hline $\operatorname{EOM}\left(\mathrm{kg} \mathrm{Mg}^{-1}\right)$ & 130 & 165 & 217 & 369 & 148 & 671 \\
\hline $\mathrm{P}\left(\mathrm{kg} \mathrm{Mg}^{-1}\right)$ & 5.6 & 3.3 & 1.1 & 13.7 & 1.7 & 3.0 \\
\hline $\mathrm{OM} / \mathrm{P}\left(\mathrm{kg} \mathrm{kg}^{-1}\right)$ & 33 & 97 & 279 & 36 & 93 & 244 \\
\hline $\mathrm{EOM} / \mathrm{P}\left(\mathrm{kg} \mathrm{kg}^{-1}\right)$ & 23 & 49 & 204 & 27 & 86 & 222 \\
\hline \multicolumn{7}{|l|}{$\mathrm{N}$ mineralisation } \\
\hline as $\%$ of $N_{\text {tot }}$ & 22 & -7 & -6 & 25 & 15 & 5 \\
\hline as $\%$ of $N_{\mathrm{org}}$ & 81 & -13 & -7 & 27 & 15 & 7 \\
\hline
\end{tabular}

$D M$ dry matter, $O M$ organic matter, $H C$ humification coefficient, $E O M$ effective organic matter, $N_{\text {tot }}$ total nitrogen, $N_{\text {org }}$ organic nitrogen, $D E C-S F$ solid fraction after decanter, $S C P-S F$ solid fraction after screw press, $P$-POOR $S F$ solid fraction decanter and $\mathrm{P}$ stripping, $D R Y$-SF solid fraction after decanter and drying, $C O M P$ compost, $B C H R$ biochar produced from P-POOR SF 


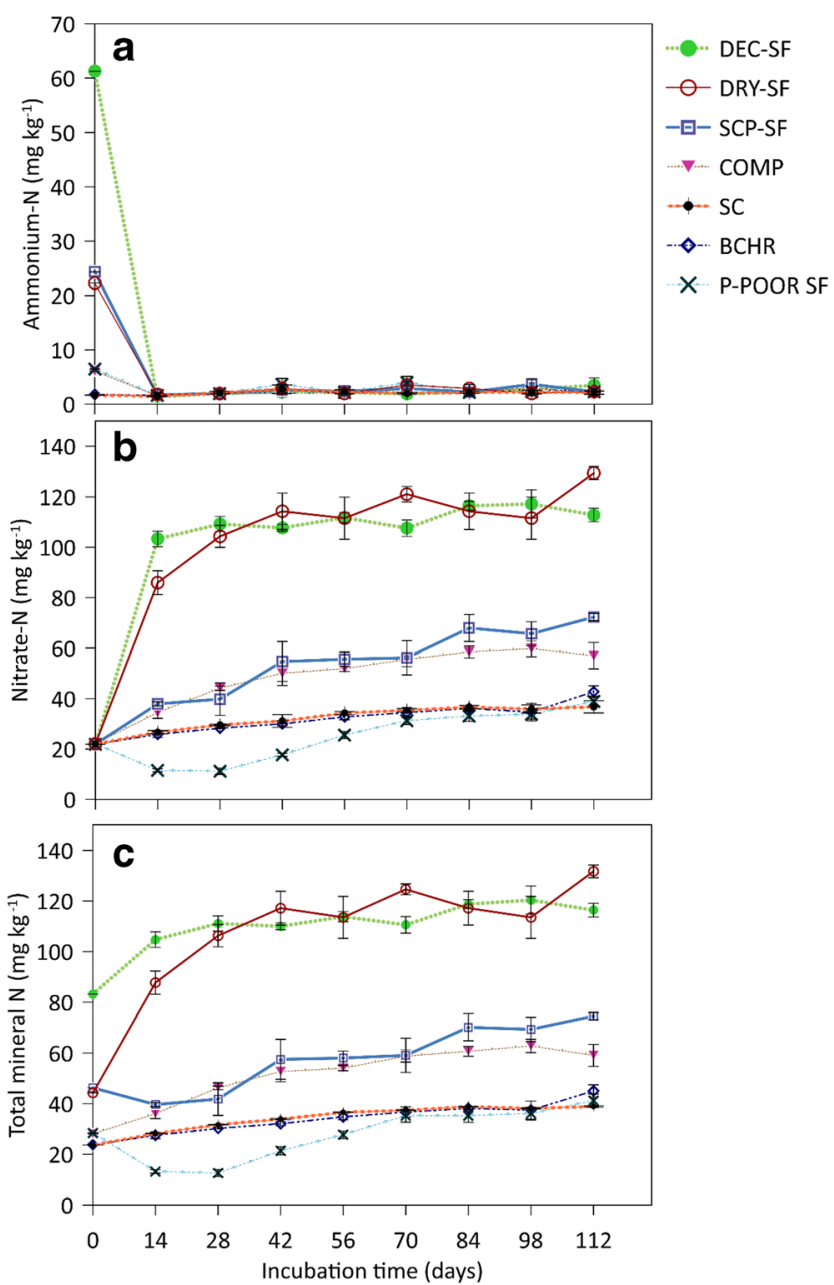

Fig. 2 Evolution of a ammonium-N $\mathbf{b}$ nitrate- $\mathrm{N}$ and $\mathbf{c}$ total mineral $\mathrm{N}$ expressed in $\mathrm{mg} \mathrm{kg}^{-1}$ in the unamended soil and soil amended with the tested biosolids during 112-day incubations at $21.5{ }^{\circ} \mathrm{C}$ (mean value \pm standard deviation, $n=4$; where absent, error bars fall within symbols). SC soil control, DEC-SF solid fraction after decanter, SCP-SF solid fraction after screw press, $\mathrm{P}-\mathrm{POOR} \mathrm{SF}$ solid fraction decanter and $\mathrm{P}$ stripping, DRY-SF solid fraction after decanter and drying, COMP compost. BCHR biochar produced from P-POOR SF

not good indicators of labile OM, at least, for the biosolids investigated in this study.

\subsection{C and $\mathrm{N}$ mineralisation}

The incorporation of the different biosolids significantly modified the $\mathrm{C}$ and $\mathrm{N}$ dynamics of the soil. Some studies (Flavel and Murphy 2006; Wang et al. 2004) have shown that dissimilarities in decomposition rates (i.e. $\% C_{\min }$ ) may be due to differences in the nature of organic carbon compounds present in the substrates. That is, mineralisation patterns in soils are mainly influenced by the initial composition of the organic material (Heal et al. 1997; Aerts 1997; Teklay et al. 2007). For example, the $\mathrm{C} / \mathrm{N}_{\text {tot }}$ ratio may influence substrate decomposition rate such that substrates with a high $\mathrm{C} / \mathrm{N}_{\text {tot }}$ ratio above 25 are poorly decomposable (Nicolardot et al. 2001). In this study, however, SCP-SF had the highest $\mathrm{C} / \mathrm{N}_{\text {tot }}$ ratio (36) and yet showed fast degradability. This was likely caused by both higher $\mathrm{C}$ and $\mathrm{N}$ availability, which was reflected by the lower WSC/WHEC to $N_{\min }$ ratio (Table 3). Such an occurrence will favour the preferential utilisation of labile biosolid-derived $\mathrm{C}$ by soil microorganisms and cause high $\mathrm{C}$ mineralisation. The corollary effect of high $\mathrm{C}$ mineralisation in SCP-SF treatment was the rapid $\mathrm{N}$ immobilisation observed in the first 28 days of the $\mathrm{N}$ incubation experiment (Fig. 3).

To an extent, P-POOR SF showed similar behaviour as SCP-SF but with moderate $\mathrm{C}$ mineralisation and less rapid $\mathrm{N}$ immobilisation. $\mathrm{N}$ mineralisation in P-POOR-SF was inhibited at the beginning but caught up with the unamended control around day 70, indicating $\mathrm{N}$ was likely immobilised by soil microorganisms and then re-released due to microbial turnover. In addition, the low $\mathrm{pH}$ of P-POOR-SF may have slowed down the turnover of microbial biomass and extended the microbial immobilisation as (a) low $\mathrm{pH}$ slows down bacterial cell division (Bååth et al. 1998) and (b) low pH favours the prevalence of soil fungi with longer life-spans (Gyllenberg and Eklund 1974). It is important to note that the mineralisation patterns of SCP-SF and P-POOR SF do suggest a re-mineralisation of the immobilised $\mathrm{N}$. Therefore, both biosolids may not be suitable for supplying $\mathrm{N}$ to crops grown during the season of application but can serve as an $\mathrm{N}$ source in the subsequent growing season.

The amendment of DEC-SF induced similar amount of C mineralised (Fig. 1) but greater $\mathrm{N}$ mineralisation when compared with DRY-SF (Figs. 1 and 2c). This observation may be explained by the "microbial $\mathrm{N}$ mining" theory (Craine et al. 2007; Moorhead and Sinsabaugh 2006) which postulates that $\mathrm{N}$ deficiency can enhance microbial decomposition of labile substrates in order to obtain $\mathrm{N}$ from recalcitrant $\mathrm{OM}$. Meaning the relatively higher $C / N_{\text {tot }}$ ratio in DEC-SF might have driven the soil microorganisms to decompose more $\mathrm{N}$-rich $\mathrm{OM}$ for their $\mathrm{N}$ requirement when compared with DRY-SF where $\mathrm{N}$ was not limited. Considering their continued net mineralisation of organic $\mathrm{N}$ (Fig. 3), DEC-SF and DRY-SF appear to hold the highest $\mathrm{N}$ fertiliser value. Given the rather slow pace of $\mathrm{N}$ release, their intended use should probably be to fertilise the soil rather than the crop, as practiced in organic farming, in order to improve soil quality and fertility (Webb et al. 2010).

Despite its low $\mathrm{C} / \mathrm{N}$ ratio, the $\mathrm{C}$ mineralisation of COMP progressed slowly (6\% after 81 days) indicating it to be more stable in soil than the digestate SFs here tested. That is because the undecomposed $\mathrm{C}$ in COMP exists in complex forms that are inherently resistant to decomposition (Robertson and Groffman 2015). Similarly, the $\mathrm{C}$ in BCHR is recalcitrant, but it is not inert and can be slowly mineralised (Singh and Cowie 2014; Zimmerman 2010). BCHR had a high $C / N_{\text {org }}$ ratio and yet showed very little $\mathrm{N}$ immobilisation. This was attributed to its high humification coefficient (91\%), meaning that there was no need for mineral $\mathrm{N}$ to sustain microbial growth. 
Table 6 Pearson correlation coefficients among parameters related to biosolid characteristics and $\mathrm{C}$ and $\mathrm{N}$ mineralisation dynamics

\begin{tabular}{|c|c|c|c|c|c|c|c|c|c|c|c|c|c|}
\hline & TOC & $N_{\text {tot }}$ & $N_{\min }$ & $C / N_{\text {tot }}$ & $C / N_{\text {org }}$ & $N_{\min } / N_{\text {tot }}$ & $N_{\text {org }} / N_{\text {tot }}$ & WSC & HWEC & $C_{A}$ & $\mathrm{HC}$ & $\% C_{\min }$ & $\% N_{\min }$ \\
\hline TOC & 1 & & & & & & & & & & & & \\
\hline$N_{\text {tot }}$ & -0.372 & 1 & & & & & & & & & & & \\
\hline$N_{\min }$ & -0.353 & -0.062 & 1 & & & & & & & & & & \\
\hline$C / N_{\text {tot }}$ & 0.273 & -0.372 & 0.005 & 1 & & & & & & & & & \\
\hline$C / N_{\text {org }}$ & 0.310 & 0.441 & -0.515 & 0.310 & 1 & & & & & & & & \\
\hline$N_{\text {min }} / N_{\text {tot }}$ & -0.390 & -0.482 & $0.855^{*}$ & 0.366 & -0.404 & 1 & & & & & & & \\
\hline$N_{\text {org }} / N_{\text {tot }}$ & 0.390 & 0.482 & $-1.000^{* *}$ & -0.366 & 0.404 & $-1.000^{* * *}$ & 1 & & & & & & \\
\hline WSC & -0.547 & -0.095 & $0.821^{*}$ & -0.434 & -0.623 & 0.617 & -0.617 & 1 & & & & & \\
\hline HWEC & -0.496 & 0.234 & 0.285 & $-0.849^{*}$ & -0.606 & -0.071 & 0.071 & 0.500 & 1 & & & & \\
\hline$C_{A}$ & -0.340 & -0.358 & 0.762 & 0.548 & -0.475 & $0.825^{*}$ & $-0.825^{*}$ & 0.376 & -0.146 & 1 & & & \\
\hline $\mathrm{HC}$ & 0.355 & 0.327 & -0.794 & -0.497 & 0.502 & $-0.824^{*}$ & $0.824^{*}$ & -0.436 & 0.112 & $-0.996^{* *}$ & 1 & & \\
\hline$\% C_{\min }$ & -0.397 & -0.234 & $0.825^{*}$ & 0.334 & -0.572 & 0.759 & -0.759 & 0.110 & -0.252 & $0.941^{* *}$ & $-0.966^{* *}$ & 1 & \\
\hline$\% N_{\min }$ & -0.065 & 0.400 & 0.331 & $-0.880^{* * *}$ & -0.104 & 0.015 & -0.015 & 0.700 & 0.572 & -0.340 & 0.276 & -0.106 & 1 \\
\hline
\end{tabular}

TOC $\left(\mathrm{g} \mathrm{kg}^{-1}\right)$ total organic carbon, $N_{\text {tot }}\left(\mathrm{g} \mathrm{kg}^{-1}\right)$ total nitrogen, $N_{\min }\left(\mathrm{g} \mathrm{kg}^{-1}\right)$ mineral nitrogen, $N_{\text {org }}\left(\mathrm{g} \mathrm{kg}^{-1}\right)$ organic nitrogen, WSC (\% of TOC) water soluble carbon, $H W E C$ (\% of TOC) hot water extractable carbon, $N_{\text {org }}$ organic nitrogen, $C_{A}$ amount of mineralisable $\mathrm{C}, H C$ humification coefficient $(\%)$, $\% C_{\min } \mathrm{C}$ mineralised as $\%$ of added $\mathrm{C}$ after 81 days of incubation, $\% N_{\min } \mathrm{N}$ mineralised as $\%$ of added organic $\mathrm{N}$ after 112 days of incubation

\subsection{Implications for using solid digestates as an organic soil improver}

The relative proportions of TOC mineralised from the tested biosolids reflect their different biostabilities in soil. Estimates of humification coefficients (HC) and effective organic matter $(\mathrm{EOM})$ are good indicators of long term availability of OM in soil after initial application of biosolids. The high EOM of DRY-SF (369 $\mathrm{kg} \mathrm{Mg}^{-1}$ ) represents a significant potential source of soil organic matter. However, its use as an organic soil improver may be limited because restrictions on $\mathrm{P}$ input in some EU regions (e.g. Belgium, The Netherlands, and Denmark) constrain the application of P-rich materials

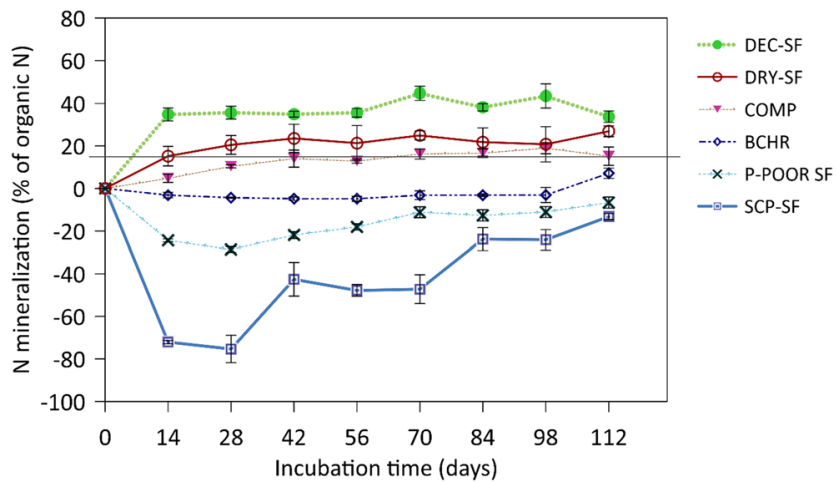

Fig. $3 \mathrm{~N}$ mineralisation (\% of organic $\mathrm{N}$ supplied (Eq. 4) from the tested biosolids) during 112 days of incubation (mean value \pm standard deviation, $n=4$; where absent, error bars fall within symbols). DEC-SF solid fraction after decanter, SCP-SF solid fraction after screw press, P-POOR SF solid fraction decanter and $\mathrm{P}$ stripping, DRY-SF solid fraction after decanter and drying, COMP compost, BCHR biochar produced from $\mathrm{P}_{-}$ POOR SF
(Amery and Schoumans 2014). The P-POOR SF, with its high $\mathrm{EOM} / \mathrm{P}$ proves to be far more advantageous in such regions. In fact, with the exception of BCHR, P-POOR SF can be applied to soil at least 2.4 times more than any of the other biosolids tested (Table 5). Furthermore, its low N-content permits the application of large amounts without violating the European Nitrates Directive (91/676/EEG; European Commission, 1991). The slow $\mathrm{N}$ mineralisation of P-POOR SF also makes it ideal for use as an exclusively organic soil improver in regions with restrictions on $\mathrm{P}$ and $\mathrm{N}$ additions to soils.

P-stripping, as an additional treatment step, may thus be a promising technique for valorisation of SFs of digestate. Pyrolysis of the SFs (of P-POOR SF in this study) increased OM stability but still appears unwarranted to promote pyrolysis as a sustainable post-treatment, especially considering the high production costs involved (Campbell et al. 2018). Composting of SFs has been proposed by some studies as a viable alternative to increase its biological stability (de la Fuente et al. 2013; Torres-Climent et al. 2015). However, a study carried out by Tambone et al. (2015) showed that composting did not remarkably increase the stability of SFs and Möller (2015) argued that digestate composting may reduce the fertiliser's nutrient value and may cause greenhouse gas emissions. Given the already high stability of the tested SFs, except for SCP-SF, it again seems likely that composting would not further valorise the SFs as soil improvers and the extra economic costs involved may be unfavourable. In any case, the here observed differences in the composition and mineralisation rates of SFs from digestate processing highlight the need for detailed analyses before using them as soil amendments. 


\section{Conclusions}

The $\mathrm{C}$ and $\mathrm{N}$ mineralisation potential of P-POOR SF was compared with conventional SFs of digestate to study the stability of the present OM. The results showed that the humification coefficient does not correlate with the $\mathrm{C} / \mathrm{N}$ ratio, HWEC or WSC. It therefore seems that the nature of the organic matter was the main factor controlling $\mathrm{C}$ mineralisation in the treatments. Temporary $\mathrm{N}$ immobilisation was observed in P-POOR SF and SF after screw press (SCP$\mathrm{SF}$ ), and this was attributed to their high $C / N_{\text {org }}$ ratios. In biochar (BCHR), no $\mathrm{N}$ immobilisation was observed despite its high $C / N_{\text {org }}$ ratio which is due to the high humification coefficient $(91 \%)$ of the biosolid, meaning that there was no need for mineral $\mathrm{N}$ to sustain microbial growth. The other tested biosolids, SF after decanter (DEC-SF), SF after decanter and drying (DRY-SF), and compost, showed a near linear positive $\mathrm{N}$ mineralisation. There was no correlation between the $\mathrm{HC}$ and $\% \mathrm{~N}$ mineralisation. When considering the amount of effective organic matter (EOM) that can be applied to soils within the phosphate limits, i.e. the EOM/P ratio, P-POOR SF had the highest potential to be used as an organic soil improver among the SFs. As such, reducing the P concentration in SFs facilitates their application in many European soils. These results highlight the agricultural value of SFs of digestate for soil organic matter and their potential limitations in P-rich soils.

Funding The research is done as part of the SYSTEMIC project that receives funding from the European Union's Horizon 2020 Framework Programme for Research and Innovation under Grant Agreement no. 730400. See www.systemicproject.eu and www.biorefine.eu/projects/ systemic for more information.

Open Access This article is licensed under a Creative Commons Attribution 4.0 International License, which permits use, sharing, adaptation, distribution and reproduction in any medium or format, as long as you give appropriate credit to the original author(s) and the source, provide a link to the Creative Commons licence, and indicate if changes were made. The images or other third party material in this article are included in the article's Creative Commons licence, unless indicated otherwise in a credit line to the material. If material is not included in the article's Creative Commons licence and your intended use is not permitted by statutory regulation or exceeds the permitted use, you will need to obtain permission directly from the copyright holder. To view a copy of this licence, visit http://creativecommons.org/licenses/by/4.0/.

\section{References}

Aerts R (1997) Climate, leaf litter chemistry and leaf litter decomposition in terrestrial ecosystems: a triangular relationship. Oikos 79:439 449

Alburquerque JA, de la Fuente C, Ferrer-Costa A, Carrasco L, Cegarra J, Abad M, Bernal MP (2012) Assessment of the fertiliser potential of digestates from farm and agroindustrial residues. Biomass
Bioenergy 40:181-189. https://doi.org/10.1016/j.biombioe.2012. 02.018

Amery F, Schoumans OF (2014) Agricultural phosphorus legislation in Europe. ILVO Report, Merelbeke.

Anderson JPE (1982) Soil respiration. In: Page AL, Miller RH, Keeney DR (eds) Methods of soil analysis, part 2. Chemical and microbiological properties, 2nd edn. American Society of Agronomy, Madison, pp 831-871

Bååth E, Frostegård Å, Díaz-Raviña M, Tunlid A (1998) Microbial community-based measurements to estimate heavy metal effects in soil: the use of phospholipid fatty acid patterns and bacterial community tolerance. Ambio 27:58-61. https://doi.org/10.2307/ 4314686

Calderón FJ, McCarty GW, Reeves JB (2005) Analysis of manure and soil nitrogen mineralization during incubation. Biol Fert Soils 41: 328-336. https://doi.org/10.1007/s00374-005-0843-x

Campbell RM, Anderson NM, Daugaard DE, Naughton HT (2018) Financial viability of biofuel and biochar production from forest biomass in the face of market price volatility and uncertainty. Appl Energ 230:330-343. https://doi.org/10.1016/j.apenergy.2018.08. 085

Chatterjee R, Gajjela S, Thirumdasu RK (2017) Recycling of organic wastes for sustainable soil health and crop growth. Int J Waste Resour 07:03. https://doi.org/10.4172/2252-5211.1000296

Craine JM, Morrow C, Fierer N (2007) Microbial nitrogen limitation increases decomposition. Ecology 88:2105-2113. https://doi.org/ 10.1890/06-1847.1

de la Fuente C, Alburquerque JA, Clemente R, Bernal MP (2013) Soil C and $\mathrm{N}$ mineralisation and agricultural value of the products of an anaerobic digestion system. Biol Fert Soils 49:313-322. https://doi. org/10.1007/s00374-012-0719-9

De Neve S, Hofman G (2000) Influence of soil compaction on carbon and nitrogen mineralization of soil organic matter and crop residues. Biol Fert Soils 30:544-549. https://doi.org/10.1007/s003740050034

De Neve S, Sleutel S, Hofman G (2003) Carbon mineralization from composts and food industry wastes added to soil. Nutr Cycl Agroecosys 67:13-20. https://doi.org/10.1023/A:1025113425069

EBA (2018) EBA Statistical Report. In European Biogas Association. Retrieved from http://european-biogas.eu/2017/12/14/ebastatistical-report-2017-published-soon/. Accessed 25 Jan 2019

Egene CE, Van Poucke R, Ok YS, Meers E, Tack FMG (2018) Impact of organic amendments (biochar, compost and peat) on $\mathrm{Cd}$ and $\mathrm{Zn}$ mobility and solubility in contaminated soil of the Campine region after three years. Sci Total Environ 626:195-202. https://doi.org/10. 1016/j.scitotenv.2018.01.054

European Commission (1991) Directive of the Council of 12 December 1991 concerning the protection of waters against pollution caused by nitrates from agricultural sources $(91 / 676 /$ EC). Official Journal of the European Communities, L375, 0001- 0008

European Commission (2019) Regulation (EU) 2019/1009 of 5 June 2019 laying down rules on the making available on the market of EU fertilising products and amending Regulations (EC) No 1069/ 2009 and (EC) No 1107/2009 and repealing Regulation (EC) No 2003/2003. In Official Journal of the European Union (Vol. 2019)

Flavel TC, Murphy DV (2006) Carbon and nitrogen mineralization rates after application of organic amendments to soil. J Environ Qual 35: 183-193. https://doi.org/10.2134/jeq2005.0022

Ghani A, Dexter M, Perrott KW (2003) Hot-water extractable carbon in soils: a sensitive measurement for determining impacts of fertilisation, grazing and cultivation. Soil Biol Biochem 35:12311243. https://doi.org/10.1016/S0038-0717(03)00186-X

Gyllenberg HG, Eklund E (1974) The organisms: bacteria. In: Dickinson CH, Pugh GJF (eds) Biology of plant litter decomposition. Academic Press, London, pp 245-269

Heal OW, Anderson JM, Swift MJ (1997) Plant litter quality and decomposition: an historical overview. In: Cadish G, Giller KE (eds) 
Driven by nature, plant litter quality and decomposition. $\mathrm{CAB}$ International, Wallingford, pp 47-66

Holm-Nielsen JB, Al Seadi T, Oleskowicz-Popiel P (2009) The future of anaerobic digestion and biogas utilization. Bioresour Technol 100: 5478-5484. https://doi.org/10.1016/j.biortech.2008.12.046

Juma NG (1999) Introduction to soil science and soil resources (the pedosphere and its dynamics: a systems approach to soil science) (Vol. 1). Salman Productions, Edmonton

Linn DM, Doran JW (1984) Effect of water-filled pore space on carbon dioxide and nitrous oxide production in tilled and nontilled soils. Soil Sci Soc Am J 48:1267-1272

Lugato E, Bampa F, Panagos P, Montanarella L, Jones A (2014) Potential carbon sequestration of European arable soils estimated by modelling a comprehensive set of management practices. Glob Change Biol 20:3557-3567. https://doi.org/10.1111/gcb.12551

Mendham DS, Heagney EC, Corbeels M, O'Connell AM, Grove TS, McMurtrie RE (2004) Soil particulate organic matter effects on nitrogen availability after afforestation with Eucalyptus globulus. Soil Biol Biochem 36:1067-1074. https://doi.org/10.1016/j.soilbio. 2004.02.018

Möller K (2015) Effects of anaerobic digestion on soil carbon and nitrogen turnover, $\mathrm{N}$ emissions, and soil biological activity. A review. Agron Sustain Dev 35:1021-1041. https://doi.org/10.1007/s13593015-0284-3

Moorhead DL, Sinsabaugh RL (2006) A theoretical model of litter decay and microbial interaction. Ecol Monogr 76:151-174. https://doi.org/ 10.1890/0012-9615(2006)076[0151:ATMOLD]2.0.CO;2

Muhammad W, Vaughan SM, Dalal RC, Menzies NW (2011) Crop residues and fertilizer nitrogen influence residue decomposition and nitrous oxide emission from a Vertisol. Biol Fert Soils 47:1523. https://doi.org/10.1007/s00374-010-0497-1

Nicolardot B, Recous S, Mary B (2001) Simulation of C and N mineralisation during crop residue decomposition : a simple dynamic model based on the C:N ratio of the residues. Plant Soil 228:83103. https://doi.org/10.1023/A:1004813801728

Nishanth D, Biswas DR (2008) Kinetics of phosphorus and potassium release from rock phosphate and waste mica enriched compost and their effect on yield and nutrient uptake by wheat (Triticum aestivum). Bioresour Technol 99:3342-3353. https://doi.org/10. 1016/j.biortech.2007.08.025

Peters K, Jensen LS (2011) Biochemical characteristics of solid fractions from animal slurry separation and their effects on $\mathrm{C}$ and $\mathrm{N}$ mineralisation in soil. Biol Fert Soil 47:447-455. https://doi.org/ 10.1007/s00374-011-0550-8

Pognani M, D’Imporzano G, Scaglia B, Adani F (2009) Substituting energy crops with organic fraction of municipal solid waste for biogas production at farm level: a full-scale plant study. Process Biochem 44:817-821. https://doi.org/10.1016/j.procbio.2009.03. 014

Postma R, Ros G (2016) Rapport 1580 Bepalen van stabiliteit van GFTen groencomposten. Wageningen

Regelink I, Ehlert P, Smit G, Everlo S, Prinsen A, Schoumans O (2019) Phosphorus recovery from co-digested pig slurry: development of the RePeat process. Retrieved from www.wur.eu/environmentalresearch. Accessed 30 Nov 2019

Robertson GP, Groffman PM (2015) Nitrogen transformations. In soil microbiology, ecology and biochemistry, 4th edn. Academic Press, pp 421-446. https://doi.org/10.1016/b978-0-12-415955-6. 00014-1

Schoumans OF, Ehlert PAI, Regelink IC, Nelemans JA, Noij GAM, van Tintelen W, Rulkens WH (2017) Chemical phosphorus recovery from animal manure and digestate. https://oi.org/10.18174/426297

Sigurnjak I, De Waele J, Michels E, Tack FMG, Meers E, De Neve S (2017) Nitrogen release and mineralization potential of derivatives from nutrient recovery processes as substitutes for fossil fuel-based nitrogen fertilizers. Soil Use Manag 33:437-446. https://doi.org/10. 1111/sum. 12366

Singh BP, Cowie AL (2014) Long-term influence of biochar on native organic carbon mineralisation in a low-carbon clayey soil. Sci Rep 4:3687. https://doi.org/10.1038/srep03687

Sleutel S, De Neve S, Prat Roibás MR, Hofman G (2005) The influence of model type and incubation time on the estimation of stable organic carbon in organic materials. Eur J Soil Sci 56:505-514. https:// doi.org/10.1111/j.1365-2389.2004.00685.x

Tambone F, Terruzzi L, Scaglia B, Adani F (2015) Composting of the solid fraction of digestate derived from pig slurry: biological processes and compost properties. Waste Manag 35:55-61. https://doi. org/10.1016/j.wasman.2014.10.014

Teklay T, Nordgren A, Nyberg G, Malmer A (2007) Carbon mineralization of leaves from four Ethiopian agroforestry species under laboratory and field conditions. Appl Soil Ecol 35:193-202

Torres-Climent A, Martin-Mata J, Marhuenda-Egea F, Moral R, Barber X, Perez-Murcia MD, Paredes C (2015) Composting of the solid phase of digestate from biogas production: optimization of the moisture, $\mathrm{C} / \mathrm{N}$ ratio, and $\mathrm{pH}$ conditions. Commun Soil Sci Plan 46:197207. https://doi.org/10.1080/00103624.2014.988591

Van Poucke R, Egene CE, Allaert S, Lebrun M, Bourgerie S, Morabito D, Ok YS, Ronsse F, Meers E, Tack FMG (2020) Application of biochars and solid fraction of digestate to decrease soil solution $\mathrm{Cd}, \mathrm{Pb}$ and $\mathrm{Zn}$ concentrations in contaminated sandy soils. Environ Geochem Health 42:1589-1600. https://doi.org/10.1007/s10653019-00475-4

Van Ranst E, Verloo M, Demeyer A, Pauwels JM (1999) Manual for the soil chemistry and fertility laboratory. Ghent University, Faculty Agricultural and Applied Biological Sciences

Veeken A, Adani F, Fangueiro D, Jensen S (2017) The value of recycling organic matter to soils classification as organic fertiliser or organic soil improver. EIP-AGRI Focus Group - Nutrient Recycling, 10. Retrieved from http://circulairterreinbeheer.nl/wp-content/uploads/ 2017/10/Value-of-organic-matter-Classification-as-fertiliser-orsoil-improver_final-23-Jan-2017.pdf. Accessed 02 Dec 2019

Wagner GH, Wolf DC (1999) Carbon transformations and soil organic matter formation. In: Sylvia DM, Fuhrmann JJ, Hartel PG, Zuberer DA (eds) Principles and applications of soil microbiology. Prentice Hall, New Jersey, pp 218-258

Wang P, Changa CM, Watson ME, Dick WA, Chen Y, Hoitink HAJ (2004) Maturity indices for composted dairy and pig manures. Soil Biol Biochem 36:767-776

Webb J, Sørensen P, Velthof G, Amon B, Pinto M, Rodhe L, Salomon E, Hutchings N, Burczyk P, Reid J (2010) Study on variation of manure $\mathrm{N}$ efficiency throughout Europe. AEA Technology plc, Didcot, pp 1-114

Weigel A, Eustice T, Antwerpen RV, Naidoo G, Schulz E (2011) Soil organic carbon (SOC) changes indicated by hot water extractable carbon (HWEC). Proc S Afr Sug Technol Ass 84:210-222

Wood PM (1988) Biological ammonia oxidation. Cole JA, Ferguson SJ (Eds.), The nitrogen and sulphur cycles. Forty-Second Symposium of the Society for General Microbiology, University of Southampton, Cambridge University Press, Cambridge, pp 224-243

Zimmerman AR (2010) Abiotic and microbial oxidation of laboratoryproduced black carbon (biochar). Environ Sci Technol 44:12951301. https://doi.org/10.1021/es903140c

Publisher's note Springer Nature remains neutral with regard to jurisdictional claims in published maps and institutional affiliations. 